\title{
Biosorption of Arsenic(III) from Aqueous Solutions by Modified Fungal Biomass of Paecilomyces sp.
}

\author{
Ismael Acosta Rodríguez, ${ }^{1}$ Víctor M. Martínez-Juárez, ${ }^{2}$ Juan F. Cárdenas-González, \\ and María de Guadalupe Moctezuma-Zárate ${ }^{1}$ \\ ${ }^{1}$ Universidad Autónoma de San Luis Potosí, Facultad de Ciencias Químicas, Centro de Investigación y de Estudios de Posgrado, \\ Laboratorio de Micología Experimental, Avendia Dr. Manuel Nava No. 6, Zona Universitaria, 78320 San Luis Potosí, SLP, Mexico \\ 2 Área Académica de Medicina Veterinaria y Zootecnia, Instituto de Ciencias Agropecuarias, Universidad Autónoma del Estado de \\ Hidalgo, Zona Universitaria, Rancho Universitario Km 1, 43600 Tulancingo de Bravo, HGO, Mexico
}

Correspondence should be addressed to Ismael Acosta Rodríguez; iacosta@uaslp.mx

Received 30 April 2013; Revised 6 August 2013; Accepted 7 August 2013

Academic Editor: Ian Butler

Copyright (C) 2013 Ismael Acosta Rodríguez et al. This is an open access article distributed under the Creative Commons Attribution License, which permits unrestricted use, distribution, and reproduction in any medium, provided the original work is properly cited.

The biosorption of As(III) on iron-coated fungal biomass of Paecilomyces sp. was studied in this work. It was found that the biomass was very efficient removing the metal in solution, using Atomic Absorption, reaching the next percentage of removals: $64.5 \%$. The highest adsorption was obtained at $\mathrm{pH} 6.0$, at $30^{\circ} \mathrm{C}$ after 24 hours of incubation, with $1 \mathrm{mg} / \mathrm{L}$ of modified fungal biomass.

\section{Introduction}

Arsenic, a common element in nature, is a naturally occurring contaminant of drinking water and can be found in the earth's crust, ground, and marine water and in the organic world as well. It is mobilized through a combination of natural processes such as weathering reactions, biological activity, and volcanic emissions $[1,2]$ as well as through a range of anthropogenic activities such as gold mining, nonferrous smelting, petroleum refining, combustion of fossil fuel in power plants, and the use of arsenical pesticides and herbicides $[3,4]$. Contaminated groundwater by arsenic is a well-known environmental problem that can have severe human health implications. Chronic exposure to arsenic concentrations above $100 \mathrm{ppb}$ can cause vascular disorders, such as dermal pigments (Blackfoot disease) and skin, liver, and lung cancer $[5,6]$. An arsenic concentration of $10 \mu \mathrm{g} / \mathrm{L}$ has been recommended by World Health Organization as a guideline value for drinking water [7].

Arsenic is found in soils and natural waters, mainly, in the form of arsenate [As(V)] and arsenite [As(III)]. The distribution between dissolved As(III) and As(V) is dependent on redox potential and $\mathrm{pH}$. Under oxidizing conditions, the predominant specie is As $(\mathrm{V})$, which exists as deprotonated oxyanions of arsenic acid $\left(\mathrm{H}_{2} \mathrm{AsO}^{4-}, \mathrm{HAsO}_{4}{ }^{2-}\right.$, and $\left.\mathrm{AsO}_{4}{ }^{3-}\right)$. Under reducing conditions, As(III) is thermodynamically stable and exists in solution as arsenious acid, a neutral, uncharged molecule $\left(\mathrm{H}_{3} \mathrm{AsO}_{3}{ }^{0}\right)$ that only forms deprotonated oxyanions at $\mathrm{pH}>9.2\left(\mathrm{H}_{2} \mathrm{AsO}^{3-}\right.$ and $\left.\mathrm{HAsO}_{3}{ }^{2-}\right)[8]$. The As(III) species are more toxic than $\mathrm{As}(\mathrm{V})$. At the $\mathrm{pH}$ of most natural soils and water, As(III) is not strongly adsorbed on most mineral surfaces because is electrically neutral compared with the negatively charged of As(V) oxyanions [9].

Iron oxide-coated sand was used in many studies for arsenic removal, and the results were positives [10], and with modified [iron(III) loaded] orange juice industrial residue, [11], with Penicillium purpurogenum [12], enhancement in arsenate removal by chemically (polyelectrolyte, dodecylamine, and cetyltrimethylammonium bromide) modified Penicillium chrysogenum compared with the unmodified biomass [13], the biovolatilization of As by Aspergillus clavatus, Aspergillus niger, Trichoderma viride, and Penicillium glabrum [14], the biological removal of arsenic pollution by Aspergillus and Trichoderma, Neocosmospora sp., Sordaria sp., Rhizopus sp., Penicillium sp., and sterile mycelia strain fungal groups [15], and the modified fungal biomass of $A$. niger [16]. The objective of this work was to study the removal of 
Arsenic(III) in solution by the modified fungal biomass of Paecilomyces sp.

\section{Experimental}

2.1. Microorganism and Culture Conditions. A chromate resistant filamentous fungus was isolated from polluted air with industrial vapors, near of Chemical Science Faculty, located in the city of San Luis Potosí, Mexico, in Petri dishes containing modified Lee's minimal medium [LMM, 16] [with $0.25 \% \mathrm{KH}_{2} \mathrm{PO}_{4}, 0.20 \% \mathrm{MgSO}_{4}, 0.50 \%\left(\mathrm{NH}_{4}\right)_{2} \mathrm{SO}_{4}, 0.50 \%$ $\mathrm{NaCl}, 0.25 \%$ glucose] supplemented with $500 \mathrm{mg} / \mathrm{L} \mathrm{K}_{2} \mathrm{CrO}_{4}$; the $\mathrm{pH}$ of the medium was adjusted and maintained at 5.3 with $100 \mathrm{mMol} / \mathrm{L}$ citrate-phosphate buffer. The cultures were incubated at $28^{\circ} \mathrm{C}$ for 7 days. The strain was identified based on their morphological structures such as color, diameter of the mycelia, and microscopic observation of spores [17]. The fungus was grown at $28^{\circ} \mathrm{C}$ in agitation and aerated liquid media containing thioglycolate broth, $8 \mathrm{~g} / \mathrm{L}$. After $4-5$ days of incubation, the cells were centrifuged at $3000 \mathrm{rpm}$ for $10 \mathrm{~min}$, washed twice with trideionized water, and then dried at $80^{\circ} \mathrm{C}$ for $4 \mathrm{~h}$ in oven. Finally, the fungal biomass was milled and stored in an amber bottle in the refrigerator until their use.

2.2. Arsenic(III) Solutions. For analysis, a series of solutions of Arsenic(III) $\left(\mathrm{NaAsO}_{2}\right)$ of $1 \mathrm{mg} / \mathrm{L}$ were prepared, $\mathrm{pH}$ was adjusted with nitric acid and/or $\mathrm{NaOH}$, and the quantity of biomass added to each flask was of $1 \mathrm{~g} / 100 \mathrm{~mL}$ for the arsenic's solution. It took samples at different times, the biomass is removed for centrifugation $(3000 \mathrm{rpm} / 5 \mathrm{~min})$, and the supernatant is analyzed to define the ion metal concentration.

2.3. Preparation of Iron Oxide-Coated Biomass. A total $80 \mathrm{~mL}$ of the $2 \mathrm{M} \mathrm{Fe}\left(\mathrm{NO}_{3}\right)_{3} \cdot 9 \mathrm{H}_{2} \mathrm{O}$ was prepared, and $1.0 \mathrm{~mL}$ of $10 \mathrm{M}$ $\mathrm{NaOH}$ was added to this solution and mixed thoroughly. A total $20 \mathrm{~g}$ of the fungal biomass powder was taken in a porcelain pot, a mixture of iron oxide and $\mathrm{NaOH}$ solution was added to the porcelain pot and homogenized and kept in an oven for $3 \mathrm{~h}$, at $80^{\circ} \mathrm{C}$. After $3 \mathrm{~h}$ the oven temperature was raised to $110^{\circ} \mathrm{C}$ and continued for $24 \mathrm{~h}$. The coated biomass powder was separated by crushing with mortar and pestle [16].

2.4. Determination of Arsenic(III). The concentration of arsenic ions in solution was determined spectrophotometrically by Atomic Absorption (Atomic Absorption Spectrometer Varian, Model Spectra AA-20).

\section{Results and Discussion}

3.1. Arsenic Removal by Untreated and Iron Oxide-Coated Biomass at Different $p H$. Figure 1 shows the effect of untreated and iron-coated biomass and $\mathrm{pH}$ on biosorption of As(III) ions ( $1 \mathrm{mg} / \mathrm{L}, 24 \mathrm{~h})$ to the dried Paecilomyces sp. biomass. It was found that the removal is very low in untreated biomass, because at $24 \mathrm{~h}$ of incubation and $\mathrm{pH}$ 7.0 , there is an $8.4 \%(0.084 \mathrm{mg} / \mathrm{L})$ of removal (Figure 1$)$, and these results are better than those reported for $A$. clavatus,

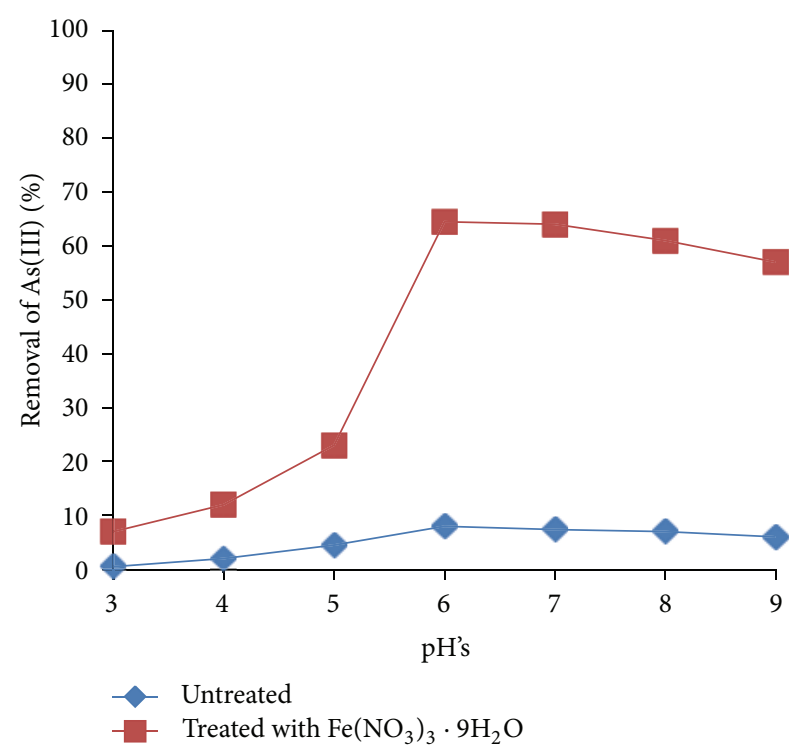

Figure 1: As(III) removal by untreated and treated iron-coated biomass at different pH's. $1 \mathrm{mg} / \mathrm{L} \mathrm{As}(\mathrm{III}), 30^{\circ} \mathrm{C}, 100 \mathrm{rpm}, 1 \mathrm{~g}$ of fungal biomass of Paecilomyces sp.

A. niger, T. viride, and P. glabrum [14], which were able to remove between 0.010 to $0.067 \mu \mathrm{g} / \mathrm{L}$, and they are lower than Penicillium purpurogenum, 3.4 (mg/g of biomass) [12], and stem of Acacia nilotica, $0.19 \mathrm{mg} / \mathrm{L}$ [18]. Structural properties of the biosorbent including the cellular support and other several factors are known to affect the biosorption rate [19]. With respect to an iron-coated biomass, the removal of As(III) is very efficient (64.5\%, pH 6.0, 24h) (Figure 1). As(III) is better adsorbed or greater than $\mathrm{pH} 6.0$ because it is partially ionized in $\mathrm{H}_{2} \mathrm{AsO}^{-}$form at a $\mathrm{pH}$ of 6.0 or above 9.22 and form complexes with the iron oxide-coated biomass. At higher $\mathrm{pH}, \mathrm{OH}^{-}$ions in the solution increase compete with the arsenate ions, and the adsorption of As(III) is reduced [20]. Considering that there was no other chemical reaction between the iron oxide and the biomass, mechanism of As(III) removal could be similar to arsenic adsorption on iron oxide-coated sand [10]. These results are similar to the other reports: by iron(III)-poly (hydroxamic acid) complex [3], iron oxide-coated sand [10], chemically modified fungal biomass [13], iron oxide-coated biomass of $A$. niger [16], mixed metal oxide impregnated chitosan beads [20], and modified iron activated carbon [21].

3.2. The Effect of Incubation Time. The biosorption of As(III) onto iron-coated biomass, with different time (0$24 \mathrm{~h}) \mathrm{As}(\mathrm{III})$, solutions of $1 \mathrm{mg} / \mathrm{L}$, at $\mathrm{pH} 6.0$, and $1 \mathrm{~g} / \mathrm{L}$ of dosage of biosorbent material, is shown in Figure 2. The sorption study of As(III) ions onto biosorbent material as a function of contact time showed that sorption is optimum at $24 \mathrm{~h}$, which indicates availability of the biosorption sites. The kinetics of sorbent metal interaction at optimum $\mathrm{pH}$ may be acknowledged to enhance accessibility of the chelating sites of the biosorbent material [22]. Further increase in time, no significant enhancements were observed in removal of 


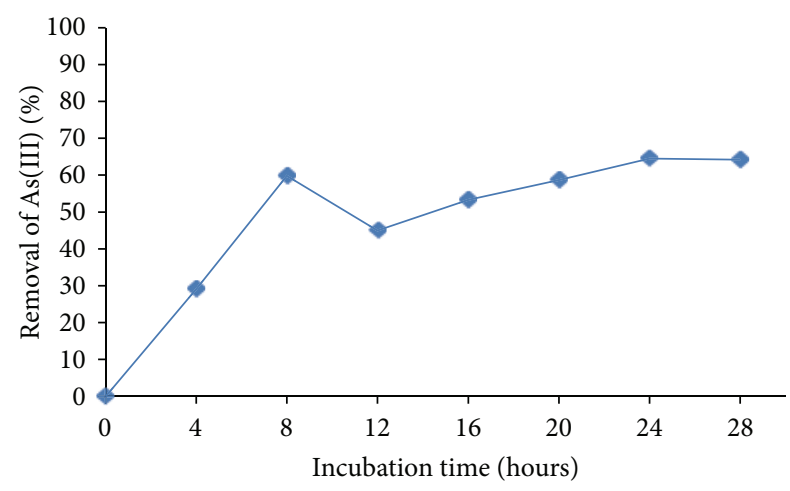

Figure 2: The effect of the Incubation time of As(III). $1 \mathrm{mg} / \mathrm{L}$ As(III), $30^{\circ} \mathrm{C}, 100 \mathrm{rpm}, \mathrm{pH} 6.0,1 \mathrm{~g}$ of iron-coated fungal biomass of Paecilomyces sp.

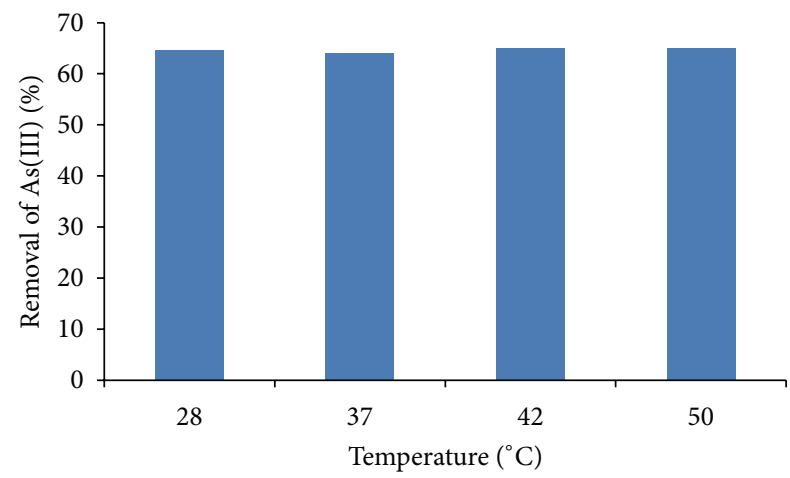

Figure 3: The effect of the temperature on As(III) removal. $1 \mathrm{mg} / \mathrm{L}$ As(III), $100 \mathrm{rpm}, \mathrm{pH} 6.0,1 \mathrm{~g}$ of iron-coated fungal biomass of Paecilomyces sp.

As(III). These results are similar for modified iron activated carbon, with a removal of $1 \mathrm{mg} / 100 \mathrm{~mL}$ at $24 \mathrm{~h}$ [21], and are different to the others reports: iron oxide-coated biomass of A. niger, $80.1 \mathrm{mg} / \mathrm{L}, 12 \mathrm{~h}$ ) [16], and with powder of stem of Acacia nilotica, (0.19 mg/L, $15 \mathrm{~min}, 4 \mathrm{~g}$ of biomass) [18].

3.3. Effect of Temperature. Figure 3 shows the effect of different temperatures $\left(30^{\circ} \mathrm{C}, 37^{\circ} \mathrm{C}, 42^{\circ} \mathrm{C}\right.$, and $\left.50^{\circ} \mathrm{C}\right)$. The adsorption capacity was similar in all temperatures analyzed (64\%$65 \%)$, and similar to the reported for iron oxide-coated biomass of $A$. niger, [16], and different of $A$. nilotica [18]. The temperature of the adsorption medium could be important for energy-dependent mechanisms in metal biosorption by microorganisms. Energy independent mechanisms are less likely to be affected by temperature since the process responsible for biosorption is largely physicochemical in nature. The biosorption of As(III) by Paecilomyces sp. fungus seems to be nondependent of the temperature tested $\left(30-50^{\circ} \mathrm{C}\right)$.

3.4. Effect of Initial As(III) Concentration. Biosorption capacities of the Paecilomyces sp. iron-coated biomass for the As(III) ions were studied as a function of the initial As(III) ions concentration between 1 and $5 \mathrm{mg} / \mathrm{L}$ in the biosorption medium (Figure 4). The uptake of As(III) found to increase

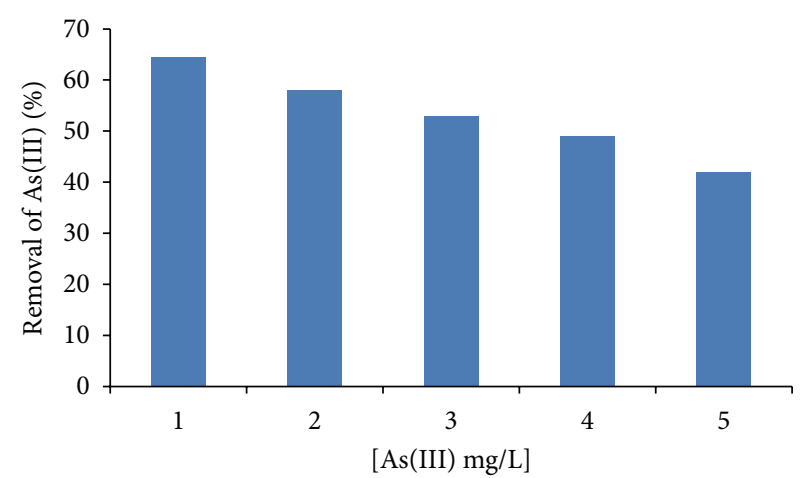

FIGURE 4: The effect of the concentration of As(III) in solution on the removal of $\mathrm{As}$ (III) ions. $100 \mathrm{rpm}, 30^{\circ} \mathrm{C}$, $\mathrm{pH} 6.0,1 \mathrm{~g}$ of iron-coated fungal biomass of Paecilomyces sp.

as the initial metal concentration is low. It was because the number of ions adsorbed from solutions of lower concentrations is more than that removed from high concentrated solutions. The uptake of As(III) was observed $64.5 \%$ and $58 \%$ at lower concentrations (1-2 mg/L) and $49 \%$ and $42 \%$ at higher concentrations (4-5 mg/L). A similar type of trend was reported for the removal of As(III) with stem of $A$. nilotica [18] and $\mathrm{Hg}(\mathrm{II})$ from aqueous solution by sorption on $R$. oligosporus [23]. Although a direct comparison between the examined treated biomass with those obtained in literature is difficult, due to the varying experimental conditions employed, Paecilomyces sp. iron-coated biomass showed reasonably high sorption efficiency as compared with other adsorbents. More specifically, green algae Ulothrix cylindricum, Fe(III)-treated biomass of Staphylococcus Xylosus, Inonotus hispidus biomass, and $\mathrm{Al} / \mathrm{Fe}$ modified montmorillonite exhibited higher biosorption capacities of As(III) at $67.2,54.35,51.9$, and $18.19 \mathrm{mg} / \mathrm{g}$, respectively, [24-27], whereas other biosorbents including Acidithiobacillus ferrooxidans BY-3, Bacillus sp. strain DJ-1, agricultural residues, modified fungal biomass of $A$. niger, and iron oxide-coated sand exhibited lower values of maximum uptake capacity at $277.22 \mu \mathrm{g} / \mathrm{g}, 6.14 \mu \mathrm{g} / \mathrm{g}, 138.88 \mu \mathrm{g} / \mathrm{g}, 75 \mu \mathrm{g} / 100 \mathrm{mg}$, and $41.1 \mu \mathrm{g} / \mathrm{g}$, for As(III), respectively, [10, 16, 28-30]. Taking into consideration that Paecilomyces $\mathrm{sp}$. has been previously used for the effective removal of $\mathrm{Cr}(\mathrm{VI})$ [31], the results of this study render this strain is very efficient adsorbents for the removal of toxic ions from aqueous environments.

\subsection{Effect of Initial Biomass Concentration and Application} on Natural Water. The influence of biomass on the removal capacity of As(III) was depicted in Figure 5. If we increase the amount of biomass also increases the removal of the metal in solution $(88.3 \%$ of removal, with $5 \mathrm{~g}$ of fungal biomass at 24 hours), with more biosorption sites of the same, because the amount of added biosorbent determines the number of binding sites available for metal biosorption [24]. Similar results have been reported for stem of A. nilotica [18] and for iron modified activated carbon [21].

Finally, this study has demonstrated the potential of iron-coated fungal biomass for the removal of As(III) at 
TABLE 1: Removal of As(III) of natural water contaminated with $1.0 \mathrm{mg} / \mathrm{L}$ of As(III), $5 \mathrm{~g}$ of iron-coated biomass, $100 \mathrm{rpm}, 30^{\circ} \mathrm{C}, \mathrm{pH}$ 6.5 (adjusted), $24 \mathrm{~h}$ of incubation.

\begin{tabular}{lccc}
\hline $\begin{array}{l}\text { As(III) } \\
\text { concentration }\end{array}$ & Before biosorption & After biosorption & Removal \\
\hline$(\mathrm{mg} / \mathrm{L})$ & $1.0(100 \%)$ & $0.270(27 \%)$ & $0.730(73 \%)$ \\
\hline
\end{tabular}

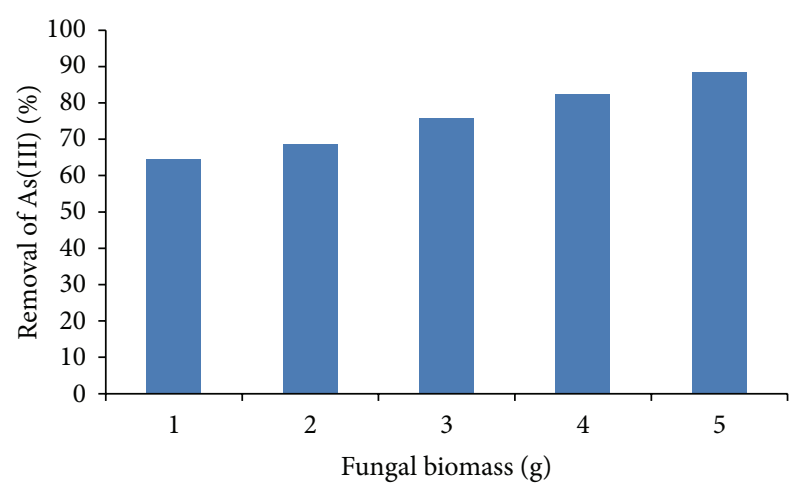

Figure 5: The effect of fungal biomass concentration on the removal of As(III). $1 \mathrm{mg} / \mathrm{L} \mathrm{As}(\mathrm{III}), 100 \mathrm{rpm}, 30^{\circ} \mathrm{C}, \mathrm{pH} 6.0$.

different conditions. The most attractive proposition of the biosorbent material is that it can be grown in large quantities and is cheap. The biosorbent material was successfully used for the removal of As from water samples of pole water samples having $1.0 \mathrm{mg} / \mathrm{L}$, precedent of Zimapan, Hidalgo state, México. The mean results of water quality before and after biosorption of studied water samples are shown in Table 1 . The water sample studied area is highly contaminated with As $(0.6 \mathrm{mg} / \mathrm{L})$ due to a natural contamination of the subterranean water [32-34], which indicated that it was out of the maximum allowable limit for drinking water $(0.05 \mathrm{mg} / \mathrm{L})$, according to NOM-127-SSA1-1994. Currently, it is $0.025 \mathrm{mg} / \mathrm{L}$, according to NOM-127-SSA1-1994-2000 (1994) $[35,36]$. It may be seen that after biosorption of As(III), this was reduced to a value of $0.270 \mathrm{mg} / \mathrm{L}$, showing the efficiency of biosorbent material for the removal of As(III) ions from pole water samples, and the results are similar for arsenical removal with stem of A. nilotica, Ionic Exchange Resins, and Maracuyá $[18,37,38]$.

\section{Conclusion}

In this study, As(III) uptake by iron-coated fungal biomass was investigated. The performance of the biosorbents was examined as a function of the operating conditions, in particular incubation time, $\mathrm{pH}$ and initial metal ion concentration, and fungal biomass. The experimental evidence shows a strong effect of the experimental conditions. Maximum biosorption capacity values showed that the modified biosorbent used is very effective in recovery or removal of As(III) ions from aquatic systems. When the ease of production and economical parameters is concerned, it was observed that Paecilomyces sp. is a very promising biomaterial for removal or recovery of the metal ion studied.

\section{References}

[1] B. K. Biswas, J.-I. Inoue, K. Inoue et al., "Adsorptive removal of $\mathrm{As}(\mathrm{V})$ and $\mathrm{As}(\mathrm{III})$ from water by a $\mathrm{Zr}(\mathrm{IV})$-loaded orange waste gel," Journal of Hazardous Materials, vol. 154, no. 1-3, pp. 10661074, 2008.

[2] P. L. Smedley and D. G. Kinniburgh, "A review of the source, behaviour and distribution of arsenic in natural waters," Applied Geochemistry, vol. 17, no. 5, pp. 517-568, 2002.

[3] M. J. Haron, W. M. Z. Wan Yunus, N. L. Yong, and S. Tokunaga, "Sorption of arsenate and arsenite anions by iron(III)poly(hydroxamic acid) complex," Chemosphere, vol. 39, no. 14, pp. 2459-2466, 1999.

[4] C. P. Huang and P. L. K. Fu, "Treatment of arsenic (V)containing water by the activated carbon process," Journal of the Water Pollution Control Federation, vol. 56, no. 3, pp. 233-242, 1984.

[5] J. M. Desesso, C. F. Jacobson, A. R. Scialli, C. H. Farr, and J. F. Holson, "An assessment of the developmental toxicity of inorganic arsenic," Reproductive Toxicology, vol. 12, no. 4, pp. 385-433, 1998.

[6] W. Wang, L. Yang, S. Hou, J. Tan, and H. Li, "Prevention of endemic arsenism with selenium," Current Science, vol. 81, no. 9, pp. 1215-1218, 2001.

[7] A. Maiti, S. DasGupta, J. K. Basu, and S. De, "Adsorption of arsenite using natural laterite as adsorbent," Separation and Purification Technology, vol. 55, no. 3, pp. 350-359, 2007.

[8] B. A. Manning and S. Goldberg, "Adsorption and stability of arsenic(III) at the clay mineral-water interface," Environmental Science and Technology, vol. 31, no. 7, pp. 2005-2011, 1997.

[9] M. Brewster, "Removing arsenic from contaminated waste water," Water Environmental Technology, vol. 4, pp. 54-57, 1992.

[10] O. S. Thirunavukkarasu, T. Viraraghavan, and K. S. Subramanian, "Arsenic removal from drinking water using iron oxidecoated sand," Water, Air, and Soil Pollution, vol. 142, no. 1-4, pp. 95-111, 2003.

[11] K. N. Ghimire, K. Inoue, K. Makino, and T. Miyajima, "Adsorptive removal of arsenic using orange juice residue," Separation Science and Technology, vol. 37, no. 12, pp. 2785-2799, 2002.

[12] R. Say, N. Yilmaz, and A. Denizli, "Biosorption of cadmium, lead, mercury, and arsenic ions by the fungus Penicillium purpurogenum," Separation Science and Technology, vol. 38, no. 9, pp. 2039-2053, 2003.

[13] M. X. Loukidou, K. A. Matis, A. I. Zouboulis, and M. Liakopoulou-Kyriakidou, "Removal of As(V) from wastewaters by chemically modified fungal biomass," Water Research, vol. 37, no. 18, pp. 4544-4552, 2003.

[14] M. Urík, S. Čerňanský, J. Ševc, A. Šimonovičová, and P. Littera, "Biovolatilization of arsenic by different fungal strains," Water, Air, and Soil Pollution, vol. 186, no. 1-4, pp. 337-342, 2007.

[15] P. K. Srivastava, A. Vaish, S. Dwivedi, D. Chakrabarty, N. Singh, and R. D. Tripathi, "Biological removal of arsenic pollution by soil fungi," Science of the Total Environment, vol. 409, no. 12, pp. 2430-2442, 2011.

[16] D. Pokhrel and T. Viraraghavan, "Arsenic removal from an aqueous solution by a modified fungal biomass," Water Research, vol. 40, no. 3, pp. 549-552, 2006.

[17] M. P. Kirk, F. P. Cannon, C. J. David, and A. J. Stalpers, Dictionary of the Fungi, CABI Publishing, Wallingford, UK, 2001.

[18] J. A. Baig, T. G. Kazi, A. Q. Shah et al., "Biosorption studies on powder of stem of Acacia nilotica: removal of arsenic from 
surface water," Journal of Hazardous Materials, vol. 178, no. 1-3, pp. 941-948, 2010.

[19] A. Aragón, B. Thomson, and J. Chwirka, "Rapid small-scale column testing for arsenicadsorption," http://ipec.utulsa.edu/ Conf2002/aragon_thomson_chwirka_50.pdf.

[20] J. S. Yamani, S. M. Miller, M. L. Spaulding, and J. B. Zimmerman, "Enhanced arsenic removal using mixed metal oxide impregnated chitosan beads," Water Research, vol. 46, pp. 44274434, 2012.

[21] W. Chen, R. Parette, J. Zou, F. S. Cannon, and B. A. Dempsey, "Arsenic removal by iron-modified activated carbon," Water Research, vol. 41, no. 9, pp. 1851-1858, 2007.

[22] N. Raje and K. K. Swain, "Purification of arsenic contaminated ground water using hydrated manganese dioxide," Journal of Radioanalytical and Nuclear Chemistry, vol. 253, no. 1, pp. 7780, 2002.

[23] H. D. Ozsoy, "Biosorptive removal of $\mathrm{Hg}$ (II) ions by Rhizopus oligosporus produced from corn-processing wastewater," African Journal of Biotechnology, vol. 9, no. 51, pp. 8791-8799, 2010.

[24] M. Tuzen, A. Sari, D. Mendil, O. D. Uluozlu, M. Soylak, and M. Dogan, "Characterization of biosorption process of As(III) on green algae Ulothrix cylindricum," Journal of Hazardous Materials, vol. 165, no. 1-3, pp. 566-572, 2009.

[25] S. Mamisahebei, G. R. Jahed Khaniki, A. Torabian, S. Nasseri, and K. Naddafi, "Removal of arsenic from an aqueous solution by pretreated waste tea fungal biomass," Iranian Journal of Environmental Health Science and Engineering, vol. 4, no. 2, pp. 85-92, 2007.

[26] A. Sari and M. Tuzen, "Biosorption of As(III) and As(V) from aqueous solution by macrofungus (Inonotus hispidus) biomass: equilibrium and kinetic studies," Journal of Hazardous Materials, vol. 164, no. 2-3, pp. 1372-1378, 2009.

[27] A. Ramesh, H. Hasegawa, T. Maki, and K. Ueda, "Adsorption of inorganic and organic arsenic from aqueous solutions by polymeric Al/Fe modified montmorillonite," Separation and Purification Technology, vol. 56, no. 1, pp. 90-100, 2007.

[28] L. Yan, H. Yin, S. Zhang, F. Leng, W. Nan, and H. Li, "Biosorption of inorganic and organic arsenic from aqueous solution by Acidithiobacillus ferrooxidans BY-3," Journal of Hazardous Materials, vol. 178, no. 1-3, pp. 209-217, 2010.

[29] D. N. Joshi, S. J. S. Flora, and K. Kalia, "Bacillus sp. strain DJ-1, potent arsenic hypertolerant bacterium isolated from the industrial effluent of India," Journal of Hazardous Materials, vol. 166, no. 2-3, pp. 1500-1505, 2009.

[30] D. Ranjan, M. Talat, and S. H. Hasan, "Biosorption of arsenic from aqueous solution using agricultural residue 'rice polish"' Journal of Hazardous Materials, vol. 166, no. 2-3, pp. 1050-1059, 2009.

[31] J. F. Cárdenas-González and I. Acosta Rodríguez, "Hexavalent Chromium removal by a Paecilomyces sp. Fungal strain isolated from environment," Bioinorganic Chemistry and Applications, vol. 2010, Article ID 676243, 6 pages, 2010.

[32] M. M. Dubinin and L. V. Radushkevich, "The equation of the characteristic curve of the activated charcoal," Proceedings of the USSR Academy of Sciences, vol. 55, pp. 331-337, 1947.

[33] M. A. Armienta, R. Rodríguez, and O. Cruz, "Arsenic content in hair of people exposed to natural arsenic polluted groundwater at Zimapan, Mexico," Bulletin of Environmental Contamination and Toxicology, vol. 59, no. 4, pp. 583-589, 1997.
[34] E. Flores, A. Armienta, S. Micete, and M. R. Valladares, "Tratamiento de agua para consumo humano con alto contenido de arsénico: estudio de un caso en zimapan, HidalgoMéxico," Información Tecnológica, vol. 20, no. 4, pp. 85-93, 2009.

[35] NOM-127-SSA1-1994-2000, Norma Oficial Mexicana sobre Salud ambiental, agua para uso y consumo humano-límites permisibles de calidad y tratamiento que debe someterse al agua para su potabilización, México D.F. , 1994.

[36] NOM 014-SSA1, Norma Oficial Mexicana sobre parámetros a determinar y la forma correcta de llevar el muestreo, conservación y manejo de las muestras hasta su ingreso al laboratorio, México D.F. , 1993.

[37] F. Prieto-García, F. Pérez Moreno, and Y. Marmolejo, "Study of arsenic removal with ionic exchange resins in drinking water from Zimapan, Hidalgo State, Mexico," International Journal of Applied Science and Technology, vol. 2, no. 6, pp. 14-16, 2012.

[38] A. Liná, J. L. Martínez- Hernández, E. P. Segura-Ceniceros, J. A. Villarreal-Sánchez, and K. M. Gregorio-Jáuregui, "Biosorción de Arsénico en materiales derivados de Maracuyá," Revista Internacional de Contaminación Ambiental, vol. 25, no. 4, pp. 201-216, 2009. 

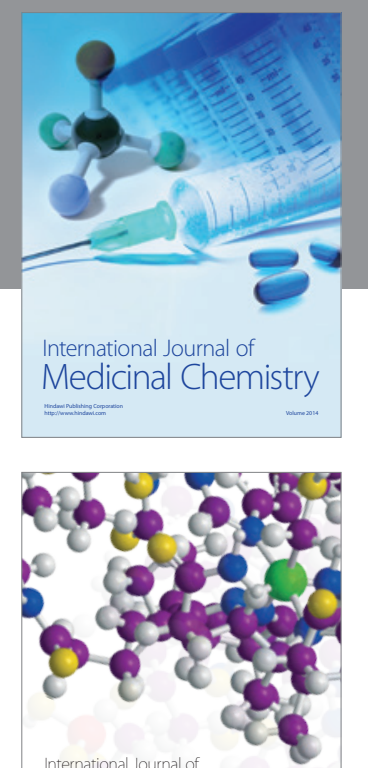

\section{Carbohydrate} Chemistry

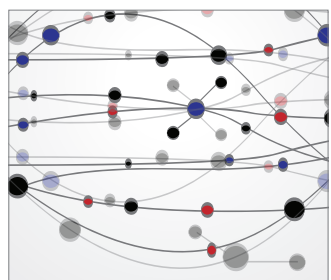

The Scientific World Journal
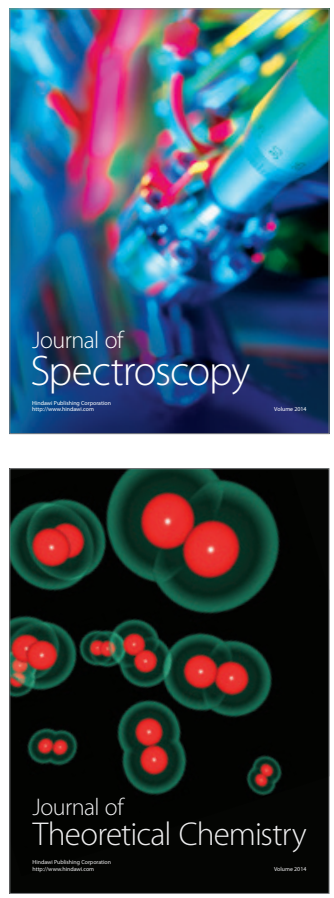
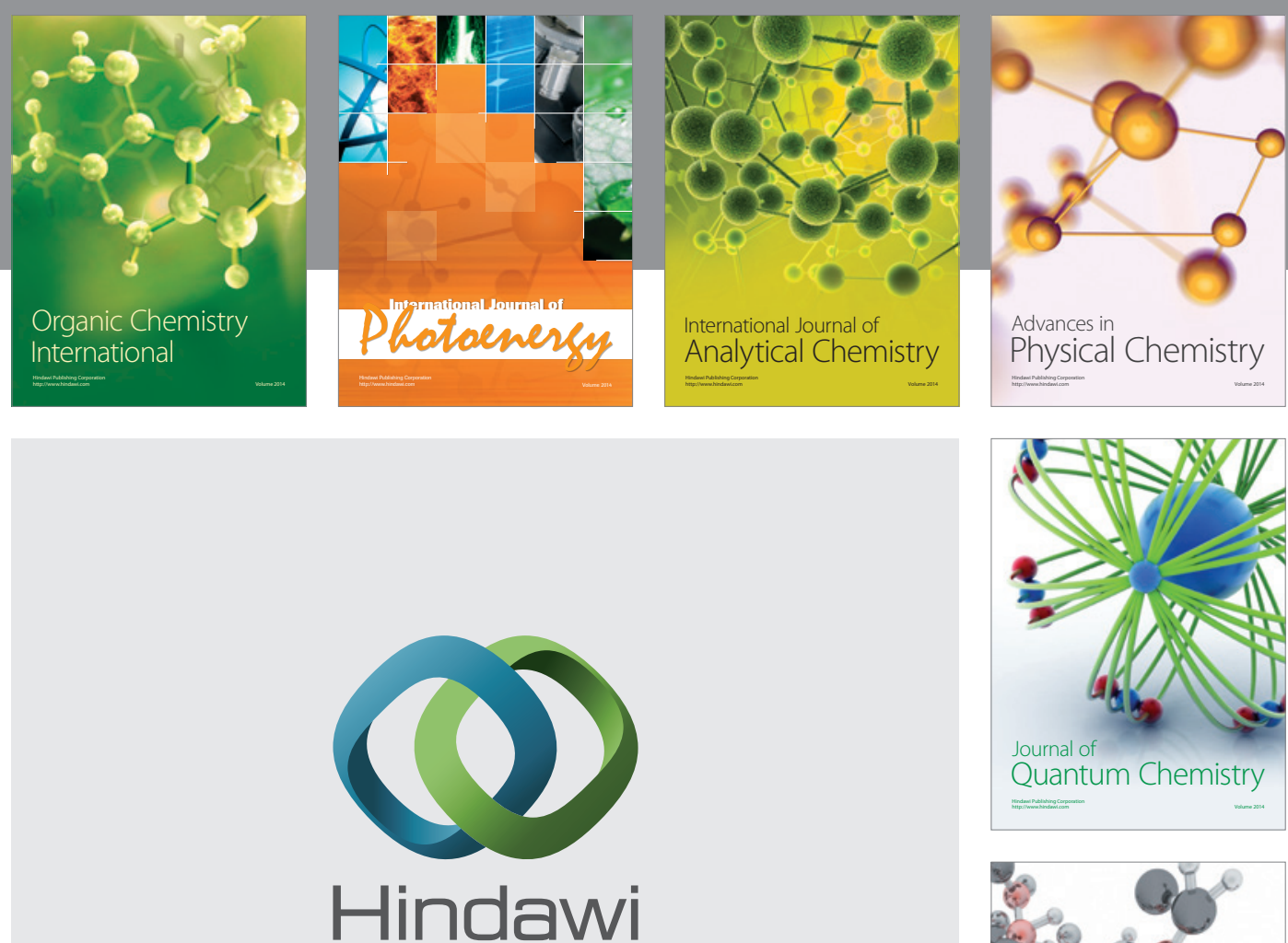

Submit your manuscripts at

http://www.hindawi.com

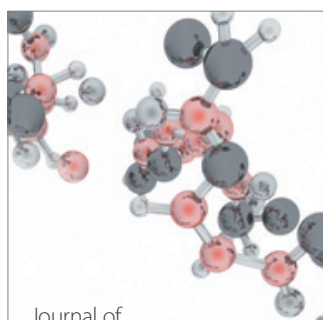

Analytical Methods

in Chemistry

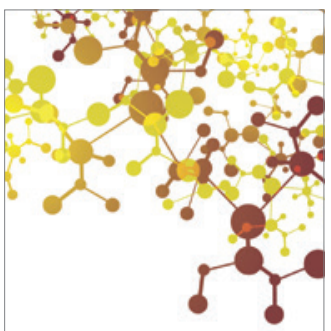

Journal of

Applied Chemistry

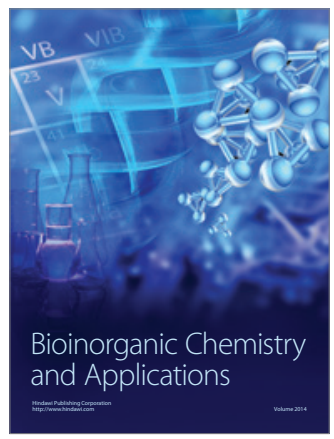

Inorganic Chemistry
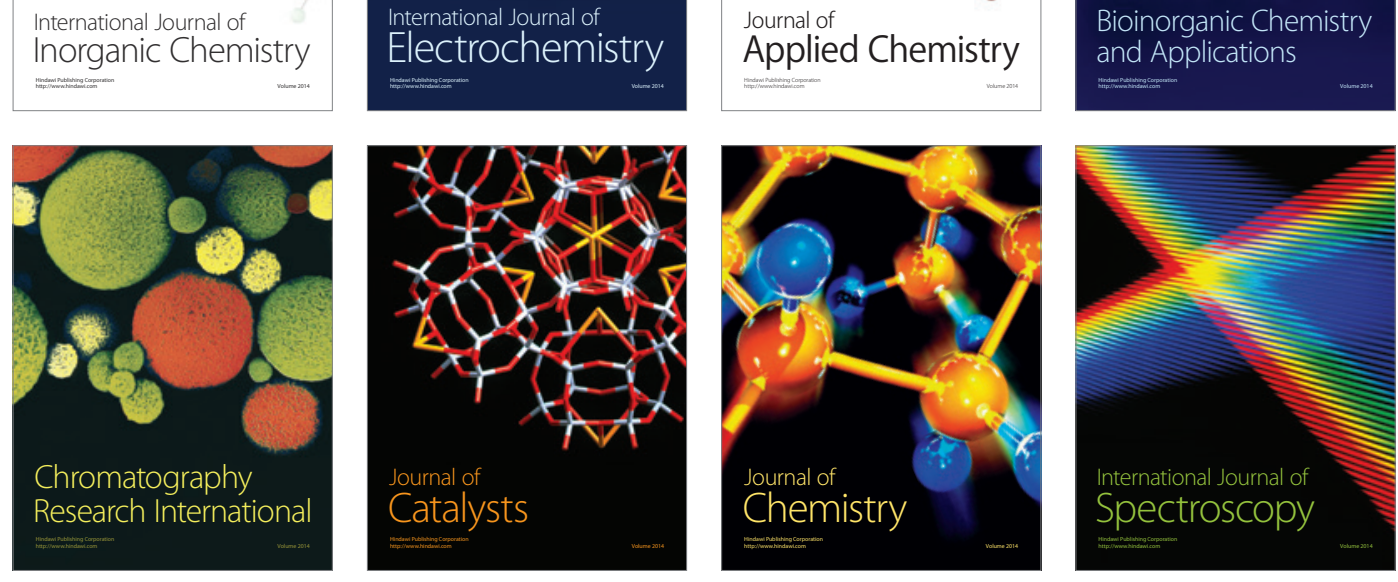